\title{
Contesting the cruel treatment of abortion-seeking women Ruth Fletcher
}

Dr Ruth Fletcher, Senior Lecturer in Medical Law, Queen Mary University of London Mile End Road London E1 4NS UK http://www.law.qmul.ac.uk/staff/fletcher.html

Please cite the published version: (2014) Reproductive Health Matters 22(44): 10-21; DOI: http://dx.doi.org/10.1016/S0968-8080(14)44818-3 via http://www.rhmelsevier.com/article/S0968-8080(14)44818-3/fulltext

\begin{abstract}
This article draws on legal arguments made by civil society organisations to challenge the legal reasoning that apparently produced the decision in the Ms Y case in August 2014. I show how legal standards of reasonableness and practicality ought to be interpreted in ways that are respectful of the patient's wishes and rights. The case concerned a decision by the Health Service Executive (HSE), the Irish public health authority, to refuse an abortion to a pregnant asylum seeker and rape survivor on the grounds that a caesarean section and early live delivery were practicable and reasonable alternatives justified by the need to protect foetal life. I argue that the abortion refusal may not have been a reasonable decision as required by the terms of relevant legislation for four different reasons. First, the alternative of a caesarean section and early live delivery was not likely to avert the risk of suicide, and in fact did not do so. Second, the consent to the caesarean section alternative may not have been a real consent in the legal sense if it was not voluntary. Third, an abortion refusal and forcible treatment fall below the norms of good medical practice as interpreted through a patient-centred perspective. Fourth, an abortion refusal that entails forms of cruel, inhumane and degrading treatment ought not be a 'reasonable' action under the legislation.
\end{abstract}

\section{Key words}

Abortion; refusal of treatment; caesarean section; rape; asylum; Ireland; cruel, inhuman and degrading treatment; consent; human rights; negligence

When cases like that of Ms Y come to public attention, they provoke outrage and dismay as people respond to the effects of abortion restrictions on real women's lives.[1] [2] How could a health care system treat a distressed pregnant asylum-seeking rape survivor so badly? Why weren't her requests for help in accessing an abortion acted on more quickly and effectively? The story of Ms Y, like that of Savita Halappanavar, "Beatriz", Sarah Catt [3] [4] [5] and many other women before her, draw people into the international struggle for reproductive rights. But they also remind us of the harsh effects of the legal gaze on individual women. As this issue of RHM reflects on the use of law, I want to consider how we might pull that gaze away from the scrutiny of individual women like Ms Y. How can we draw on civil society engagements with sexual and reproductive rights to redirect that gaze so that it lights up more respectful pathways for all abortion-seekers?

Ms $Y$ had the full force of law brought to bear on her reproductive body as a caesarean section was performed on her at 25 weeks gestation in spite of her request for an abortion. [6] [7] [8] The denial of her request to control her reproductive life is problematic enough, but this response seems particularly cruel.[9] How could a public responsibility to care become a licence to torment? Why have feminist advocates, activists and academics not been more successful in changing practice, policy and law? Irish society found itself asking 
these questions a year after the adoption of its first abortion legislation[10] and almost two years after the death of Savita Halappanavar.[11] [12] In this article I want to identify some of the problematic forms of legal thinking that have led the Irish state down this path and suggest alternative routes that might have been, and might yet be, taken. In doing so, I will draw on legal arguments that have been made across Irish civil society for many years, [13] [14] but do not yet seem to have permeated state thinking yet.[15]

As of the end of October, we have no official record of what happened and are still reliant on journalistic accounts.[16] The Health Service Executive has set up an inquiry to investigate the factual circumstances of this case, which was initially due to report by the end of September but has been delayed.[17] [18] There was a High Court hearing which gave an order permitting the forcible hydration of the pregnant woman, but it has not been officially reported. [6] [16] The HSE report should provide us with a fuller picture of the factual details that gave rise to this case, while protecting the anonymity of Ms $\mathrm{Y}$. But it is worth noting that this process of investigation is likely to be found wanting as a form of inquiry into possible wrongdoing to patients.

The report itself has been limited to identifying the factual circumstances of Ms Y's treatment. There is to be no investigation of the clinical decisions themselves and no qualitative appraisal of the standard of care provided to Ms Y. A second problem concerns the process of producing the report. If inquiries into health care problems are to have legitimacy, they need to hear the evidence of those who appear to have been wronged. According to media accounts, the report was drafted and circulated to relevant agencies before Ms $Y$ and her legal representatives were consulted.[19] [20] As a result the HSE report into Ms Y's case looks like it will adopt some of the poor reporting practices evident in other investigations into women's historical mistreatment.[21] [22] [23] Given the limitations of the scope of this report, a number of civil society organisations have called for an independent inquiry along the lines of that conducted into the circumstances surrounding Savita Halappanavar's death.[24]

In any case, the basic facts that seem to have given rise to this problematic decision to refuse an abortion appear to be the following. Ms $Y$ found out that she was pregnant shortly after arriving into Ireland as an asylum seeker. She was staying in Ireland's muchcritiqued system of 'direct provision' for asylum seekers [25] when she discovered that she was about 8 weeks pregnant during a medical examination. [16] [18] Her pregnancy has resulted from rape in her home country and she said that the pregnancy was very hard to bear. She was clearly distressed and made her wish to have an abortion known. Given her status as an asylum seeker, she would have been trying to find out about abortion while negotiating with various state and independent agencies on an income of $£ 19$ a week, with no knowledge of how things work in Ireland, with little in the way of a support network, and with no freedom of movement given her precarious migration status. [26] [27]

In the Republic of Ireland, [28] [29] when women such as Ms Y are considering abortion they have three options. Like abortion-seeking women the world over, they solve their problem by travelling to another jurisdiction where abortion is more accessible. [30] [31] Irish women usually travel to the UK but also to other countries such as the Netherlands. Feminist volunteers and service providers have organised to support them at home and away. [32] [33] [34] Secondly, women order the abortion pill online from services such as Women on Web, [35] but usually have to make arrangements to travel to Northern Ireland to collect it at a post office or equivalent. This is because customs in the Republic have the power to seize the pill. Supply of prescription medicines by mail order is a criminal offence 
under the control of medicines legislation.[36] Thirdly, women in Ireland can now try and access domestic abortion care on the grounds that their life is at risk under the newly adopted Protection of Life During Pregnancy Act 2013 (PLDPA).[10] When the news broke about Ms $Y$ (originally referred to as Migrant $X$ ), it was because she seemed to have been refused an abortion under the PLDPA. It later transpired that Ms $Y$ had travelled to the UK for abortion care before being referred to the HSE panel under the PLDPA, but had been turned back by UK authorities. [37]

The trials endured by one brave woman as she sought out a way to control her life have illustrated, all too painfully, failures in the treatment of pregnant women and of precarious migrants. [38] [27] [39] This case laid bare all the concerns which organisations including the Irish Human Rights Commission, [40] the Irish Family Planning Association [41] and Doctors for Choice, [42] and had raised previously about the harmful and discriminatory effects of abortion law. How are women supposed to access life-saving abortion care when that requires the negotiation of a complex and heavily restricted health care pathway, or costly travel to another jurisdiction, travel which is visa-dependent for non-EU citizens? As the UNHRC noted in July 2014, Ireland's reliance on abortion travel has significant discriminatory effects. [43][44] Here however I want to focus on the decision to deny her an abortion under the PLDPA.

Ms $Y$ was likely to have been one of the first women to have her case assessed by a panel convened under section 9 of the PLDPA. This Act was adopted in July 2013 and came into force in January 2014 in response to the legal decision by the ECtHR in Ireland $v$ ABC [45] and to political pressure in the aftermath of outrage at the death of Savita Halappanavar in a Galway hospital in October 2012. [11][12] Women in Ireland have had an explicit constitutional right to life-saving abortion since the Attorney General $v X$ decision in 1992.[46] The Supreme Court said that Article 4033 of the Irish Constitution (adopted by the Eighth Amendment in 1983) authorised a termination of pregnancy when there was a 'real and substantial risk' to a pregnant woman's life as distinct from her health, including a risk of self-destruction. [47] But women have had no clear and effective means of implementing that constitutional right and accessing such care. This is the reason why the ECtHR found that C's Art 8 rights had been violated.[45] She had a domestic right to lifesaving abortion given her treatment for cancer was being compromised by her pregnancy, but could not access domestic abortion care and travelled abroad instead.

As Murray and Enright have commented, [48][49] the public debate over the PLDPA was frustratingly narrow. In spite of efforts to open the public debate up towards a broader approach to the value of life, commentary focused on the risk of suicide ground. The government, referring to an Attorney General opinion, argued that further liberalisation of abortion law was not possible within the parameters of Article 4033 , but did not publish that opinion or the reasons underpinning it. [50] Some academics argued alongside the campaigning group, Termination for Medical Reasons,[51] that it should be possible to legislate for abortion in the context of fatal foetal anomalies (FFA) [52] [53] [54] under the current constitutional framework. They drew on the Irish government's own argument before the ECtHR in $D v$ Ireland - that the right to life of the 'unborn' may not be engaged when a foetus is incompatible with life - in doing so [55]. Some TDs (Teachta Dala or Member of the Dáil, the directly elected house of parliament) proposed amendments which would have included termination in cases of FFA, but they were not accepted [56]. In the end, the PLDPA was adopted providing for the authorisation of a termination of pregnancy in three different sets of circumstances, in cases of emergency under section 8 , cases of a risk of loss of life from physical illness under section 7 and cases of a risk of loss of life from 
suicide under section 9.[10] The grounds require one, two and three doctors' authorisation respectively. Ms Y's circumstances of distress and reported suicide attempt at 16 weeks gestation gave rise to a claim to abortion under section 9 .

Newspaper reports suggest that a HSE panel of two psychiatrists and one obstetrician was formed to consider Ms Y's case for an abortion under section 9.[16] They made a decision at about 20 weeks gestation, or around 12 weeks after she first presented to health services. The panel found that her life was at risk, but they did not authorize an abortion. Instead it put in motion a process, which would culminate in the delivery of a live child by Caesarean section at about 25 weeks gestation and included a High Court order to hydrate Ms Y who went on hunger strike in response to the denial of her request.

The legislative framework underpinning this decision has been supplemented by implementing Guidelines.[57] A penultimate version of the latter had been circulated to 'relevant agencies' over the summer of 2014 but not made publicly available, and was published by the Guardian in August.[58] The final version was officially published on the HSE website on 19 September about 2 months after the decision in Ms Y, with some significant changes.[59] In the final version, 'termination of pregnancy' includes early live delivery by induction or caesarean section, in an interesting bit of legal redefinition. In the penultimate version, early induction or caesarean section was deemed to fall outside of the Act. In any case, section 9 and the Guidelines currently require that the three medical practitioners jointly certify in good faith that "there is a real and substantial risk of loss of the woman's life by way of suicide", that the "risk can only be averted by carrying out the medical procedure" and that "they have regard to the need to preserve unborn human life as far as practicable". The legislation is silent on the question of gestational age, but the Guidelines provide that early delivery by way of induction or caesarean section may be the most appropriate procedure (6.4).

To justify the decision to deny an abortion under section 9, the HSE appointed panel must have decided that an abortion was not the only reasonable way of averting the risk to the woman's life, given the need to preserve 'unborn' human life as far as practicable. Her constitutional right to a life-sustaining abortion was engaged, but outweighed by the possibility of delivering a live child. Their grounds for refusing this life-saving abortion seem to have been that they thought it was reasonable to perform serious abdominal surgery on a woman against her wishes in order to preserve the life of the foetus. The fact that this legal interpretation tolerates treatment against the wishes of a pregnant woman who has a constitutional right to life-saving abortion is problematic enough. The fact that it does so in circumstances where that woman is very distressed, a rape survivor, an asylum seeker and living in circumstances which justify additional support rather than added violation, is deeply worrying.

Although the woman is reported as having ultimately consented to the caesarean section, it is also reported that she did not consent initially and that the HSE were preparing to ask for a High Court order authorizing the caesarean section. In other words, the performance of a caesarean section against her wishes was clearly anticipated as the reasonable and practicable alternative to an abortion, an alternative which justified refusal of that abortion. As Maeve Taylor of the Irish Family Planning Association pointed out to me, this HSE interpretation appears to have narrowed the scope of a woman's constitutional right to lifesaving abortion under the $X$ case. The section 9 test as implemented by the Guidelines has required that abortion be the only means of saving the woman's biological life in a manner 
which adds another procedural barrier to the exercise of a woman's right under Article 403 3 and may entail cruel, inhuman and degrading treatment in the forms of forcible treatment.

This is the first troubling aspect of this case from a legal perspective. There weren't many optimistic moments during the passing of the PLDPA [48] [49]. But occasionally some of those involved clung on to the hope that at minimum the Act would enhance women's procedural rights to have their abortion requests heard in a life-saving context [see further 60]. This case however seems to have delivered on our more pessimistic interpretations of those procedural rights. The abortion approval/refusal process may in itself harm women by subjecting them to the kind of judgmental scrutiny which produces mental anguish.

Irish civil society voiced this concern to the Oireachtas (or Irish Parliament, for non-Irish speakers) before the Act was adopted, to the UNHRC in July 2014 a year after the Act was passed, and to the media all the time. Indeed, the national statutory body responsible for human rights promotion and protection, the Irish Human Rights Commission [40], noted that the Bill could be in breach of human rights norms for failure to provide effective and accessible procedures for protecting the right to life of vulnerable women and girls. The UNHRC expressed concern that the panels entail 'excessive scrutiny' in breach of civil and political rights. [44 para 9] At minimum, the HSE needs to revisit interpretation of the test under section 9, as interpreted by the Guidelines, in order to comply with the ECtHR decision in $A B C$.[45] They need to ensure that women's procedural rights deliver on the purpose for which they were intended: the provision of life-saving abortion care to women at risk of suicide in a manner which respects their Convention rights to private life and freedom from discrimination.

The second troubling aspect of this abortion refusal is that it reiterates just how unethical and rights-violating the substance of Irish abortion law is. Irish abortion law imposes cruel, inhuman and degrading treatment (CIDT), violates integrity and autonomy, discriminates against women in general, and against women with mental health issues, women with few economic resources and women with limited mobility options, in particular. It does all this to conscious, sentient, thinking, feeling pregnant people in the name of protecting unconscious and non-sentient life forms in one of the more spectacular examples of upside-down thinking in human rights discourse (for an example see Binchy, [61] for a critique of this kind of thinking see Rodley[62]). I won't address this point further here, but see any one of the six pro-choice civil society submissions to the UNHRC for the July 2014 hearings for arguments and evidence in relation to the human rights violations performed by Irish abortion law. [14] There is ample evidence of past and continued efforts to push the state further towards harm reduction and rights promotion in this context and many others. But right now, the state is not listening.

A third troubling aspect, and the main point I want to focus on in the rest of the article is the panel's apparent views of what counts as 'reasonable and practicable treatment' of women who are pregnant, at risk of suicide, survivors of rape, possibly incapacitated and of precarious migration status. They must have decided that abortion was not the only means of averting the risk to Y's life under section 9 and that the gestational stage meant that a caesarean section was 'the best course of action' under the Guidelines. I want to suggest that the HSE panel may well have been legally wrong in its assumptions about what counts as reasonable and practicable treatment, and the best course of action (hereinafter referred to collectively as 'reasonable') for the following four reasons: 
1. The abortion refusal may not have been reasonable because it was not likely to avert the risk of suicide and in fact did not avert that risk.

As Doctors for Choice have consistently argued, [63] the evidence of an obstetrician is not relevant to the assessment of suicide risk, and operates as a barrier to access on this ground. In the context of suicide risk, where the woman is severely distressed by her unwanted pregnancy and the possibility of being denied an abortion, treatment options such as $C$ section and early delivery, are not likely to address her distress and reduce risk. A C section may be a reasonable treatment option in cases of physical threat, if the woman wants, and is not threatened by, a live delivery. But it is unlikely to be a reasonable option in cases of mental anguish and suicide risk.

If the offer of a caesarean was unlikely to avert the risk of suicide and the threat to the woman's life, it was not a reasonable or practicable way of vindicating her right to life with due regard to the unborn's right to life. And indeed this seems to have been born out by the consequences of the refusal. Rather than experience some relief from her distress, her distress seems to have been exacerbated as she turned to hunger strike as a means of making herself heard. In going on hunger strike, she was acting on her threat of suicide. The risk to her life, which the HSE had an obligation to reduce, eventuated in the form of acts of self-harm through the refusal of food and water.

Given this key legal and clinical distinction between kinds of life-risk, which require different kinds of clinical expertise in their assessment, the best way to interpret the Guidelines would have been to read them narrowly as applying only to those rare cases where a suicidal woman's distress is likely to be alleviated by caesarean section and early delivery, because this accords with her wishes. Otherwise the Guidelines have introduced a foetal viability criterion as a way of limiting the scope of a woman's right to abortion due to suicide risk, in a manner which is not authorized by the legislation or the $\mathrm{X}$ case precedent.

In $X$, the Supreme Court decided that when there is a direct conflict between a woman's right to biological life and a foetal right to biological life, the woman's has to take precedence. The court was silent on the issue of whether this was limited by gestation. I would argue that it is unreasonable to think of it as limited by gestation because a woman's life should always trump a foetus's life in situations of conflict. [53] [64] [65] Of course it is possible, likely even, that a court might decide differently on the length of gestation issue, as de Londras and Graham have argued. [66] But I think there are strong legal and ethical arguments for avoiding such an interpretation since it would still require sustenance until viability and performance of serious surgery, against the woman's will.

2. The abortion refusal on grounds of the $C$ section alternative may not have been reasonable, because the $\mathrm{C}$ section was not a real, voluntary alternative for the woman in this case.

The apparent consent to the $\mathrm{C}$ section may not have been 'real' in the legal sense, potentially rendering the $C$ section a trespass on the person for which the state could be liable in civil law. In Fitzpatrick and another $v K$ and another [2008] IEHC 104, Laffoy J cites Walsh J in G V An Bord Uchtala [1980] IR 32 (SC) in emphasizing "that to be valid the consent must be 'free and willing', in other words it must be voluntary".[67] K turned on issues of capacity in the context of treatment refusal, so these comments are obiter dicta (nonbinding asides). But they are an articulation of the generally accepted legal rule that 
consent needs to be voluntary, as well as informed and capacitated, in order to be valid. [68] [69]

On the assumed facts, there seem to be two reasons why this woman's apparent consent may not meet the legal test of voluntariness. First, the HSE had already got an order for forcible hydration. Second, the HSE was planning on seeking an order for a caesarean section, if she did not consent. Asking someone to consent to a caesarean section in these circumstances seems like an invocation of a superficial 'tick box' exercise, rather than the execution of legally meaningful consent. Could her consent have been free and willing if it was obtained through the implicit threat of force? Is consent ever real if there is only one option made available? If consent was not real, then the caesarean section was a noncriminal battery (assuming the absence of bad faith) and she may have a civil case against the Health Service for trespass against the person.

The Guidelines claim, referring to the National Consent Policy, [70] that "the general principles of informed consent apply to procedures carried out under this Act in the same way as for any other medical procedure." [51 at 9.1] This seems a particularly contradictory piece of policy-writing. How can proper standards of informed consent over a caesarean section operate when the woman was being denied the alternative of abortion? If she cannot opt for an alternative then it is redundant to suggest that more information about the option she wants to refuse somehow cures the problem. It seems clear that the Department of Health, the HSE, and the committee drafting the Guidelines have not worked through the inconsistencies between pregnancy regulation and normal consent law and policy, a set of inconsistences which AIMS has raised on many occasions. [71]

3. Refusing an abortion to a woman who is at risk of suicide may not be a reasonable action because it falls below legal standards of good medical practice.

The woman in this case had a legal right to abortion on grounds of suicide risk. The norms of good medical practice, which include minimizing harms to her, as well as listening to her and taking her views seriously, should have applied in this case. [72] [73] And if doctors acted below the norms of good medical practice in treating her, they may be liable in negligence if any harm resulting from the abortion refusal was caused by that breach in standards. Proving that the abortion refusal was negligent care as a matter of law would probably be difficult in this instance since negligence law continues to adopt a more professional oriented, rather than a patient oriented, standard of care (usually known in common law as the Bolam standard, see Dunne v National Maternity Hospital [1989] IR 91 (SC) [74]).

More importantly, the professional-oriented standard that it adopts tolerates more or less any level of skilled care once it is accepted by some relevant professional. This means that if a relevant health professional thinks it is acceptable to treat women in this way, then it is difficult to prove a breach of the standard, even if goes against the mainstream views of the profession. As there are a significant number of doctors who believe that abortion is not an appropriate treatment for women at risk of suicide, it is possible that an abortion refusal may not fall below the standard as set by 'a body of professional opinion'.

As a matter of law, to find that the abortion refusal was negligent care, the refusal would have to be a "deviation from general and approved practice" such that "no medical practitioner of like specialization and skill would have followed had he been taking ordinary care". This is extremely difficult to prove and this is why it only in cases of egregious harm such as Kearney's,[75] where a symphysiotomy was performed without knowledge or 
consent after a caesarean section, that patients are likely to be successful. Surely legal standards of care do not have to demand that patients tolerate everything except the completely unsupportable.[76] We should always be arguing for a more patient-centred perspective on standards of care in medical negligence law, as well as for a more robust consent policy.[71]

Indeed the problems with negligence law in this regard have been much critiqued. [77] Many have argued that the common law should be developed in light of patients' dignitary rights to be free of non-consensual treatment. [78] This could be done through reliance on Convention rights, UN human rights norms, constitutional, common law or statutory rights in their protection of autonomy, integrity and conscience. And indeed a patient-centred perspective is having more of an impact on the standards for assessing good i.e. nonnegligent treatment. Irish law together with most other common law jurisdictions has adopted a 'reasonable patient' standard in the context of medical negligence's response to the issue of information. [79] If the courts do move more towards a patient-centred perspective in all aspects of medical negligence law, then care which fails to take patient's views of harm seriously will not be satisfactory. As Mark Murphy discussed recently, [80] 'doctors of pro-choice conscience' have consistently pushed clinical standards more towards a patient-centred, human rights norm as they argue for those standards in their clinical practice. If medical practice adopts a more patient-centred perspective, then that will also push the standards of negligence law more towards a patient-centred human rights norm.

4. Refusing an abortion is not likely to be reasonable when it entails forms of cruel, inhuman and degrading treatment in breach of international, European and arguably domestic human rights norms.

If women's constitutional and international human rights are legally significant, then the standards by which health care decisions are made have to be interpreted in light of those rights. The HSE could and should interpret the meaning of 'reasonable' in light of human rights norms. The ICCPR and ECHR clearly recognize that denying abortion to a rape victim is a form of cruel, inhuman and degrading treatment.[55] [81] Irish law has not yet taken this formal step, but clearly it should if it wants to ring true in its commitment to human rights and ethical principles. The women and couples of Termination for Medical Reasons have argued that denial of domestic abortion care to women carrying pregnancies with fatal foetal anomalies is a form of CIDT. Again their arguments are clearly supported by international and European human rights standards.[55] [82] They have made 2 formal complaints to date to the UNHRC [83] and they receive a lot of popular support from Irish society.[84] The Irish Human Rights Commission has also pointed out that the failure to provide abortion care in circumstances of serious risk to health is a breach of international human rights norms [40 at para 21]. In 2011, 52\% of general practitioners questioned for a research led survey, expressed the view that abortion should be available to women who choose it. [85] There is significant support for expanding abortion provision in Ireland, but the Irish people have never been given an opportunity to liberalise, rather than restrict, abortion law.

Irish domestic law recognises the right to autonomy [86] and the right to bodily integrity [87] as unenumerated constitutional rights. Rather than attempt a legal interpretation which would evaluate how such rights can be accommodated in light of the foetal right to life however, legal authorities generally seem to assume that women's constitutional rights are suspended during pregnancy. Women's constitutional rights, albeit as limited by Article 403 3 in the context of pregnancy, could however be interpreted in light of European and 
international human rights norms to exclude anything which amounts to CIDT. I would argue that the best way to exclude CIDT is to respect the consent rights of pregnant women more generally. This would avoid a situation where rape survivors, women who are seriously ill, and women distressed by fatal foetal anomalies among others, may be harmed further by being scrutinised in order to assess whether they meet 'exceptional grounds' for abortion. [88] Nonetheless, at minimum the HSE panel could have chosen to interpret 'practicality and reasonableness' as excluding the imposition of CIDT. But it didn't. Instead it appears to have interpreted reasonableness and practicality as ensuring the delivery of a viable foetus against a woman's will and as forcibly hydrating a woman who has already been violated through rape and is vulnerable as an asylum seeker.

\section{Conclusion}

The case has been reported in the Irish media, who have commented that the baby is doing well. This seems unlikely given birth at 25 weeks gestation approx. It provides another problematic example of 'bare life' being represented as wellness. Since August, the life of Ms $Y$ continues to be reported in the Irish media in ways that should make us uncomfortable. Why should this woman's story, like the story of too many before her, have to do the work of holding the state to account? Irish society at home and abroad has objected to the cruel treatment of this woman in its name. [89][90] But we also have to move the public gaze away from her life circumstances and towards public officials who need to be held to account. The challenge will be to do so in a way which helps rather than hinders those within the state who are pushing for better protection of reproductive rights and those who work with the state to develop more ethical practices.

The Coalition to Repeal the Eighth Amendment has acquired new momentum.[91] [92] Civil society organisations are co-operating across the full range of social justice issues as the links between freedom from deportation, access to healthcare, and respect for women's contributions are increasingly visible. Justice for Magdalenes [93] and Survivors of Symphysiotomy [94] provide shining examples of gender justice campaigns which have sought redress and accountability for women's mistreatment while rejecting calls to sensationalise and personalise that history. There is still a long way to go before we get proper state acknowledgement that life means more than bare biological existence and that women's contributions to life ought to be valued in all their varied forms. But I for one find sustenance in the Ireland that has long fought for these goals within and without the public gaze. [95]

Acknowledgements: This paper draws on the blog "Contesting the cruel treatment of pregnant women" Human Rights in Ireland. 19 August 2014.

http://humanrights.ie/constitution-of-ireland/contesting-cruel-treatment-ruth-fletcher/?

My thanks go to Mary Donnelly, Máiréad Enright, Claire Murray, Peadar O'Grady, and Maeve Taylor, for their helpful comments on an earlier version.

\section{References}

1. Fletcher R. Reducing harm to sentient beings should be central to abortion laws. The Journal. 1 September 2014. http://www.thejournal.ie/readme/abortion-laws-ireland1644005-Sep2014/

2. McDonald H. Ireland: Woman forced to give birth after being denied abortion The Guardian. 17 August 2014. http://www.theguardian.com/world/2014/aug/17/irelandwoman-forced-birth-denied-abortion

3. Holland K. Savita: The tragedy that shook a nation. Transworld Publishers, 2013 
4. Berer M. Termination of pregnancy as emergency obstetric care. Reproductive Health Matters 2013;21(41):9-17

5. Prochaska E. Sarah Catt, abortion and the legal rights of pregnant woman. The Guardian. 21 September 2012 http://www.theguardian.com/law/2012/sep/21/sarah-catt-abortionlegal-rights-pregnant

6. McDonald D. Sheahan F. Baby delivered as woman refused abortion under law. The Irish Independent. 16 August 2014. http://www.independent.ie/irish-news/health/babydelivered-as-woman-refused-abortion-under-law-30512513.html

7. Enright M. Suicide and the Protection of Life During Pregnancy Act 2013. Human Rights in Ireland. 16 August 2014 http://humanrights.ie/constitution-of-ireland/suicide-and-theprotection-of-life-in-pregnancy-act-2013/

8. Tighe M. State 'denied abortion' to rape victim. The Sunday Times. 18 August 2014 http://web.archive.org/web/20140818235517/http://www.thesundaytimes.co.uk/sto/hom eV2/article1447800.ece

9. Holland K. They said they could not do an abortion. I said 'you can leave me now to die. I don't want to live in this world anymore'. The Irish Times. 19 August 2014

http://www.irishtimes.com/news/health/they-said-they-could-not-do-an-abortion-i-saidyou-can-leave-me-now-to-die-i-don-t-want-to-live-in-this-world-anymore-1.1901258 10. Protection of Life During Pregnancy Act 2013, Act No.35 of 2013 http://www.oireachtas.ie/viewdoc.asp?fn=/documents/bills28/acts/2013/a3513.pdf 11. Health Information and Quality Authority. Investigation into the safety, quality and standards of services provided by the Health Service Executive to patients, including pregnant women, at risk of clinical deterioration including those provided by University College Galway, and as reflected in the care and treatment of Savita Halappanavar. 7 October 2013. http://www.hiqa.ie/press-release/2013-10-09-patient-safety-investigationreport-published-health-information-and-qualit. The Health Information and Quality Authority found numerous failures, including 13 missed chances to save her life.

12. Health Service Executive (The Arulkumuran Report), Investigation of Incident 50278 from time of patient's self-referral to hospital on the $21^{\text {st }}$ of October, 2012 to the patient's death on the $28^{\text {th }}$ October, 2012. June 2013.

http://www.hse.ie/eng/services/news/nimtreport50278.pdf

13. Clip from Today Tonight Referendum Special on the Eighth Amendment, RTE (Radio Telefís Eireann, the public broadcaster of radio and tv), 8 September 1983; featuring Mary Robinson of the Anti-Amendment Campaign and William Binchy of the Pro-Life Amendment Campaign https://www.youtube.com/watch?v=GLWnoQjTNiw

14. For a recent example of civil society critique of Irish state practices see the submissions to the UN Human Rights Committee for Ireland's review under the International Covenant of Civil and Political Rights (ICCPR), including six pro-choice submissions from the Abortion Rights Campaign, Centre for Reproductive Rights, Doctors for Choice, Irish Council of Civil Liberties, Irish Family Planning Association and the Women's Human Rights Alliance at: Information from Civil Society Organizations, Consideration of State Report from Ireland, 111 Session (07 July $2014-25$ July 2014), CCPR

http://tbinternet.ohchr.org/_layouts/treatybodyexternal/SessionDetails1.aspx?SessionID=6 26\&Lang=en

15. There does seem to have been conflict within the Department of Health and the HSE over how to respond to the case; see Sheehan M. Department of Health slammed HSE over Ms Y care. The Irish Independent. 28 September 2014 http://www.independent.ie/irishnews/health/department-of-health-slammed-hse-over-ms-y-care-30621236.html 16. Holland, K. Timeline of Ms Y case. The Irish Times. 4 October 2014 http://www.irishtimes.com/news/social-affairs/timeline-of-ms-y-case-1.1951699 
17. HSE statement: Protection of Life During Pregnancy Act, 2013. 18 August 2014

http://www.hse.ie/eng/services/news/media/pressrel/newsarchive/2014archive/august14/ protectionoflife.html

18. Holland $\mathrm{K}$. The terms of inquiry set into care of woman in abortion case The Irish Times.

22 August 2014 http://www.irishtimes.com/news/social-affairs/terms-of-inquiry-set-into-

care-of-woman-in-abortion-case-1.1905586

19. Holland K. Ms Y may refuse to take part in abortion inquiry over report leak. The Irish

Times. 24 September 2014 http://www.irishtimes.com/news/social-affairs/ms-y-may-

refuse-to-take-part-in-abortion-inquiry-over-report-leak-1.1939265

20. The draft report was featured on Prime Time, a leading current affairs programme, before Ms $Y$ was consulted or interviewed, and before she received a copy of it. See further Draft Report on Ms Y case. Radio Telefis Eireann (RTE). 22 September 2014.

http://www.rte.ie/news/player/prime-time/2014/0922/

21. Irish Human Rights Commission, Follow up report on State Involvement with Magdalene Laundries http://www.ihrec.ie/publications/list/ihrc-followup-report-on-state-involvementwith-mag/

22. O'Rourke M. It's time we learnt the truth about Magdalene Laundries. The Irish Independent. 5 July 2014 http://www.independent.ie/opinion/comment/its-time-we-learntthe-truth-about-magdalene-laundries-30408325.html

23. Enright M. Symphysiotomy survivors deserve improved redress, The Irish Times. 2

October 2014 http://www.irishtimes.com/news/health/symphysiotomy-survivors-deserve-

improved-redress-1.1948266

24. Joint Call for Independent Inquiry. 29 August 2014.

https://www.facebook.com/pages/Safe-and-Legal-in-Ireland-Abortion-Rights-

Campaign/140386587640

25. Thornton L. The Rights of Others: Asylum Seekers and Direct Provision in Ireland. Human Rights in Ireland. 24 June 2014. http://humanrights.ie/children-and-the-law/the-rights-ofothers-asylum-seekers-and-direct-provision-in-ireland/

26. Behan N. Ireland's law on abortion is a shambles entirely of the state's creation. The Journal. 27 September 2014 http://www.thejournal.ie/ifpa-miss-y-1691328-Sep2014/ 27. Fletcher R. Reproducing Irishness: Race, Gender and Abortion Law. Canadian Journal of Women and the Law 2005;17:365-404, see 396-402

http://papers.ssrn.com/sol3/papers.cfm?abstract_id $=2485527$

28. Women in Northern Ireland are in a similar situation given the failure to extend the Abortion Act 1967 to that part of the United Kingdom. See further McGuinness S and Fox M. The Problems of Travelling to Access Basic Care. Human Rights in Ireland.

http://humanrights.ie/constitution-of-ireland/the-problems-of-travelling-to-access-basiccare-repealthe8th/

29. Fox M. The case for decriminalizing abortion in Northern Ireland in A. Alghrani, B. Bennett and S. Ost (eds) The Criminal Law and Bioethical Conflict, Cambridge University Press, 2013, 203-219.

30. Sethna C. Doull M. Accidental Tourists: Canadian Women, Abortion Tourism, and Travel. Women's Studies International Forum 2012;41(4):457-475

31. Fletcher R. Peripheral Governance: Administering Transnational Healthcare Flows. International Journal of Law in Context. 2013;9:161-190

http://papers.ssrn.com/sol3/papers.cfm?abstract_id=2395895

32. Rossiter A. Ireland's Hidden Diaspora: The Abortion Trail and the Making of a LondonIrish Underground 1980-2000. IASC Publishing, 2009.

33. Abortion Support Network https://www.abortionsupport.org.uk 
34. Fletcher R. Civic feminism and voluntary abortion care: A story of ESCORT's contribution to reproductive justice. In Kennedy S. Quilty A. Conlon C. The Abortion Papers - Volume 2 forthcoming Cork University Press, 2015; draft on file with author.

35. https://www.womenonweb.org

36. Health Products Regulatory Authority https://www.hpra.ie

37. Holland K. Ms Y held in UK after failing to obtain abortion here. The Irish Times. 11

October 2014 http://www.irishtimes.com/news/social-affairs/ms-y-held-in-uk-after-failingto-obtain-abortion-here-1.1959893

38. Luibhéid, E. Pregnant on Arrival: Making the Illegal Immigrant. University of Minnesota Press, 2013.

39. Lentin, R. Strangers and Strollers: Feminist Notes on Researching Migrant M/others Women's Studies International Forum 2004;27(4):301-314

40. Irish Human Rights Commission Observations on the Protection of Life During Pregnancy Bill, July 2013. http://www.ihrec.ie/publications/list/ihrc-observations-protection-of-lifeduring-pregna/

41. IFPA submission to the Crisis Pregnancy Agency, 2002 http://www.ifpa.ie/MediaInfo/Publications/Submissions/IFPA-Policy-Submission-to-the-Crisis-Pregnancy-Agency

42. Doctors for Choice and BPAS, Submission to the European Court of Human Rights in ABC, 2009.

http://doctorsforchoiceireland.files.wordpress.com/2014/06/abc_brief_bpas_and_dfc.pdf 43. Clip of Professor Flinterman's comments and questions during Ireland's review under the ICCPR by the UNHRC, 15 July 2014 https://www.youtube.com/watch?v=kpzoa3140xQ 44. United Nations Human Rights Committee. Concluding Observations on the fourth periodic report of Ireland. CCPR/C/IRLCO/4.

http://tbinternet.ohchr.org/_layouts/treatybodyexternal/Download.aspx?symbolno=CCPR\% 2fC\%2fIRL $\% 2 \mathrm{fCO} \% 2 \mathrm{f} 4$ \&Lang=en

45. $A B C v$ Ireland (2010) ECtHR (Application no. 25579/05)

http://www.bailii.org/eu/cases/ECHR/2010/2032.html

46. Attorney General v X [1992] 1IR1 http://www.bailii.org/ie/cases/IESC/1992/1.html

47. Article 4033 provides "The State acknowledges the right to life of the unborn and, with due regard to the equal right to life of the mother, guarantees in its laws to respect, and, as far as practicable, by its laws to defend and vindicate that right."

http://www.irishstatutebook.ie/en/constitution/

48. Murray C. The narrative of the hysterical woman: the discourse on the inclusion of suicide in the Irish legislation on abortion. Reforming Abortion Law: Comparative

Perspectives Conference, University College Cork, 22 March 2013

http://www.ucc.ie/en/ccjhr/events/videos/ and http://rightsni.org/2013/01/legislating-forarticle-40-3-3-murray-on-hysterical-women/

49. Enright M. Abortion, unease and citizenship in Ireland. Human Rights in Ireland. 25 April 2013 http://humanrights.ie/gender-sexuality-and-the-law/abortion-unease-and-citizenshipin-ireland/

50. Regan M. Kenny rejects further abortion proposal. The Irish Examiner. 2 July 2013 http://www.irishexaminer.com/ireland/kenny-rejects-further-abortion-proposal235735.html

51. http://www.terminationformedicalreasons.com

52. Schweppe J. Spain E. When is a Foetus not an Unborn? Fatal Foetal Abnormalities and Article 403 3. Irish Journal of Legal Studies 2013:92-110

http://papers.ssrn.com/sol3/papers.cfm?abstract_id=2304252

53. Fletcher R. Submission to the Health Committee on the General Scheme of the Protection of Life During Pregnancy Bill, May 2013, in Houses of the Oireachtas Joint Committee on Health and Children, Report on Protection of Life During Pregnancy Bill 2013 
(Heads of) (Volume 1) May 2013 402-412

http://www.oireachtas.ie/parliament/media/committees/healthandchildren/Volume1.pdf and http://humanrights.ie/criminal-justice/guestpost-ruth-fletchers-submission-to-theoireachtas-abortion-hearings/

54. Letter to the Irish Times, 15 June 2013. http://humanrights.ie/constitution-ofireland/letter-to-the-irish-times-on-abortion-legislation-and-fatal-foetal-abnormalities/ 55. D v Ireland Application no. 26499/02 ECtHR (27 June 2006).

http://hudoc.echr.coe.int/sites/eng/pages/search.aspx?i=001-76233\#\{"itemid":["00176233"]\}

56. Healy S. Proposed section 10, in Committee Amendments, Protection of Life During Pregnancy Bill 2013, p. 7 available at

http://www.oireachtas.ie/documents/bills28/bills/2013/6613/b6613d-dscn.pdf; see further http://www.thejournal.ie/fatal-foetal-abnormalities-987896-Jul2013/

57. Department of Health. Implementation of the Protection of Life During Pregnancy Act 2013: Guidance Document for Health Professionals. September 2014.

http://health.gov.ie/wp-content/uploads/2014/09/Guidance-Document-Final-September2014.pdf.

58. The Guardian. 7 August 2014.

http://www.theguardian.com/world/interactive/2014/aug/07/pregnant-women-irelandabortion-ban-suicide-document

59. Holland K. Abortion Guidelines provide for induction or caesarean section. The Irish Times. 20 September 2014 http://www.irishtimes.com/news/social-affairs/abortionguidelines-provide-for-induction-or-caesarean-section-1.1935578

60. Erdman in Cook R. Dickens B. and Erdman J eds. Abortion Law in Transnational

Perspective: Cases and Controversies. University of Pennsylvania Press, 2014

http://www.upenn.edu/pennpress/book/15282.html

61. Binchy W. UN Committee's view on abortion contradicts core ethical value of human rights. The Irish Times. 18 August 2014 http://www.irishtimes.com/news/politics/uncommittee-s-view-on-abortion-contradicts-core-ethical-value-of-human-rights-1.1899802 62. Clip of closing comments by Sir Nigel Rodley during Ireland's review under the ICCPR by the UNHRC, 15 July 2014 https://www.youtube.com/watch?v=vONCIB3uHns

63. Doctors for Choice

https://doctorsforchoiceireland.files.wordpress.com/2013/04/dfc_submission_unhrc_iccpr_ final_june2014.pdf

64. Fletcher R. Reproductive Justice and Article 403 3. In Schweppe J. The Unborn Child, Article 4033 and Abortion in Ireland. Dublin. The Liffey Press. 2008

65. Fletcher R. 'Pro-life' absolutes, feminist challenges: The fundamentalist narrative of Irish abortion law 1986-1992 Osgoode Hall Law Journal 1998;36(1):1-62

http://digitalcommons.osgoode.yorku.ca/ohlj/vol36/iss1/1/

66. de Londras F. Graham L. Impossible Floodgates and Unworkable Analogies in the Irish Abortion Debate. Irish Journal of Legal Studies. 2013; pre-publication version available here: http://papers.ssrn.com/sol3/papers.cfm?abstract_id=2260134

67. http://www.bailii.org/ie/cases/IEHC/2008/H104.html

68. Donnelly M. Consent: Bridging the Gap between Doctor and Patient. Cork University Press, 2002.

69. Donnelly M. Healthcare Decision-making and the Law: Autonomy, Capacity and the Limits of Liberalism. Cambridge University Press, 2014.

70. HSE National Consent Policy

http://www.hse.ie/eng/about/Who/qualityandpatientsafety/National_Consent_Policy/

71. AIMS. Not a consent issue. 6 August 2014. http://aimsireland.ie/not-a-consent-issue/ 
72. Irish Medical Council. Guide to professional conduct and ethics for registered medical practitioners $7^{\text {th }}$ edition 2009.

73. The HSE strategic plan 2008-2013 commits to making the service user central to their own care and the design and delivery of health and personal social services.

http://www.hse.ie/eng/services/publications/corporate/Your_Service,_Your_Say_Consumer Affairs/Strategy/Service_User_Involvement.html

74. Available electronically via a fee paying legal database service such as Lexis Nexis.

75. Kearney $v$ McQuillan and North Eastern Health Board [2012] IESC 43

http://www.bailii.org/cgi-

bin/markup.cgi?doc=/ie/cases/IESC/2012/S43.html\&query=title+(+)

76. Survivors of Symphysiotomy. Submission to the UN Human Rights Committee, July 2014

http://tbinternet.ohchr.org/_layouts/treatybodyexternal/Download.aspx?symbolno=INT\%2f CCPR\%2fCSS\%2fIRL\%2f17503\&Lang=en

77. Jackson E. Informed Consent to Medical Treatment and the Impotence of Tort, in SA

McLean (ed), First Do No Harm: Law, Ethics and Healthcare. Ashgate Publishing, England 2006.

78. Manning J. Informed Consent to Medical Treatment: The Common Law and New Zealand's Code of Patient Rights. Medical Law Review 2004; 12:181-216

79. Fitzpatrick v White [2007] IESC 51 http://www.bailii.org/ie/cases/IESC/2007/S51.html 80. Murphy M. Abortion law strangled at birth by medical guidelines. The Irish Independent. 9 August 2014. http://www.independent.ie/opinion/analysis/abortion-law-strangled-atbirth-by-unworkable-guidelines-30494121.html

81. P and S v. Poland (2012) Application no. 57375/08, ECtHR available at:

http://hudoc.echr.coe.int/sites/fra/pages/search.aspx?i=001-114098

82. $R R$ v. Poland (2011) App. No. 27617/04, ECtHR available at:

http://hudoc.echr.coe.int/sites/eng/pages/search.aspx?i=001-104911

83. http://reproductiverights.org/en/press-room/CRR-brings-second-Ireland-case

84. Polls regularly record high levels of popular support e.g. $80 \%$ for the legalization of abortion in cases of FFA e.g. http://www.thejournal.ie/abortion-ireland-rape-fatal-foetalabnormality-771180-Jan2013/

85. Murphy M. et al. Termination of pregnancy: attitudes and clinical experiences of Irish GPs and GPs-in-training. European Journal of General Practice. 2012;18(3):136-142.

86. Re a Ward of Court [1996] 2 IR 79

http://www.supremecourt.ie/supremecourt/sclibrary3.nsf/(WebFiles)/C846F3E1E8CB3AA88 025765D00516026/\$FILE/Ward\%20of\%20Ct\%20(No\%202)_1995.pdf

87. Ryan v Attorney General [1965] IESC 1. http://www.bailii.org/ie/cases/IESC/1965/1.html

88. Conway V. On the difficulties of rape exceptions. Human Rights in Ireland. 13 October 2014 http://humanrights.ie/constitution-of-ireland/on-the-difficulties-of-rape-exceptionsrepealthe8th/

89. Protests planned in Dublin and Cork. The Irish Examiner. 19 August 2014

http://www.irishexaminer.com/ireland/protests-planned-in-dublin-and-galway-282479.html and see https://www.facebook.com/abortionrightscampaign

90. Speakingoflmelda https://www.youtube.com/channel/UCW_F64htch9WiH5UzONwYQg and https://www.facebook.com/pages/Speaking-of-Imelda/571659212932533

91. Conference: Building a Coalition to Repeal the $8^{\text {th }}$ Amendment. Dublin. 6 September 2014. https://www.youtube.com/playlist?list=PLLROso8j00RWPZ41z85ZWqD7onEaDoNM_ 92. Repealthe8th Blognival. Human Rights in Ireland. 13 October 2014.

http://humanrights.ie/uncategorized/blognival-repealthe8th/

93. Justice for Magdalenes http://www.magdalenelaundries.com

94. Survivors of Symphysiotomy http://symphysiotomyireland.com 
95. Woman to Blame: 40 years of struggle for contraception and abortion rights in Ireland, Filmbase. Dublin. 7-16th November 2014; as reported by McTiernan A. Retrieving 40 years of women's struggle in Ireland. The Irish Times. 6 November 2014.

http://www.irishtimes.com/news/social-affairs/retrieving-40-years-of-women-s-struggle-inireland-1.1989660 